\title{
Falls among the non-institutionalized elderly in northern Minas Gerais, Brazil: prevalence and associated factors
}

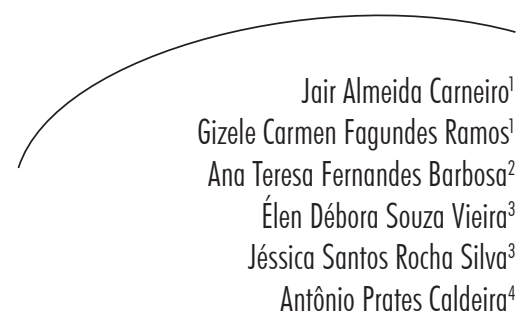

Abstract

Objective: To identify the prevalence of falls and associated factors in non-institutionalized elderly persons. Methods: A cross-sectional study featuring a population-based sample of non-institutionalized elderly persons in a city in the north of Minas Gerais was performed. Interviews were conducted in households by trained staff using validated instruments. We investigated the associations between falls and demographic, socioeconomic and health-related factors. After bivariate analysis, the variables associated with falls to a level of $20 \%$ were analyzed together using logistic regression, assuming at this stage a significance level of 5\%. Results: The studied population was predominantly female, married and with a low educational level. The prevalence of falls was $28.4 \%$. The factors that were associated with falls were: female gender (OR=1.67; 95\% CI:1.13 to 2.47); negative

Keywords: Aged. Accidental falls. Risk factors. self-evaluation of health (OR=1.49; $95 \% \mathrm{CI}: 1.02$ to 2.20$)$; impaired functional mobility (Timed Up and Go test $>20$ seconds) (OR=1.66; 95CI: 1.02-2.74); the occurrence of hospitalization in the previous 12 months (OR=1.82; 95\% CI: 1.17 to 2.84); and frailty measured by the Edmonton Frail Scale (OR=1.73; 95\% CI: 1.14 to 2.64). Conclusions: The prevalence of falls was high for the population studied and was related to the individual health conditions of the elderly.

\footnotetext{
Universidade Estadual de Montes Claros, Faculdade de Medicina, Departamento de Saúde Coletiva. Montes Claros, Minas Gerais, Brasil.

2 Universidade Estadual de Montes Claros, Faculdade de Medicina, Departamento de Clínica Médica. Montes Claros, Minas Gerais, Brasil.

3 Universidade Estadual de Montes Claros, Faculdade de Medicina, Curso de Medicina. Montes Claros, Minas Gerais, Brasil.

4 Universidade Estadual de Montes Claros, Programa de Pós-Graduação em Ciências da Saúde. Montes Claros, Minas Gerais, Brasil. 


\section{INTRODUCTION}

In recent years, the Brazilian elderly population has increased nearly twice as quickly as the general population, and is the fastest growing population segment in the country. Official records reveal that there are around 20 million people aged over 60 in Brazil at the moment, representing at least $10 \%$ of the country's population. ${ }^{1}$ This accelerated population aging has resulted in new needs and care provisions. ${ }^{2}$

One aspect that stands out in the aging process is that related to physical disabilities and the degree of dependence of the elderly. Although functional disability is not inherent in the aging process, ${ }^{3}$ as individuals age, the chance of suffering injuries caused by accidents increases. ${ }^{4}$ Studies show that such injuries are among the leading causes of death among older people and falls account for up to two thirds of accidents involving the elderly, representing one of the main predictors of morbidity and mortality. ${ }^{5-8}$

Falls in elderly people may indicate the beginning of frailty or acute disease. Besides the previously mentioned risk of death, falls result in constant injuries and fractures, compromise activities of daily living, increase rates of institutionalization, generate a decline in general health and increase fear of falling among the elderly, which, in turn, increases the risk of subsequent falls. ${ }^{9}$ Falls produce deleterious consequences not only for the elderly but also increase the cost of hospitalization and other health services, and as such represent a major public health problem. ${ }^{10}$

Adequate knowledge about the occurrence of falls in the elderly and devoting the necessary attention to the problem can guide more appropriate and effective preventive measures in health facilities. Some Brazilian studies have revealed that demographic variables may be associated with the problem, such as gender, ${ }^{11-13}$ age, ${ }^{10-14}$ the lack of a partner ${ }^{15}$ and income,${ }^{14}$ as well as health-related variables such as the presence of comorbidities, ${ }^{16-18}$ polypharmacy ${ }^{15,19}$ and selfperception of health. ${ }^{14-16}$
However, there are still variables that have been little explored in Brazilian literature, such as frailty $^{20}$ and other comorbidities. There are also no studies on the subject for the northern region of Minas Gerais. This region is characterized as a transition area between the southeast and the northeast of the country, with social indicators that demonstrate major socio-economic needs. Local studies may be representative for other regions of the country. The present study aimed to assess the prevalence of the occurrence of falls and associated factors among the elderly, investigating as yet unexplored variables in a population-based sample of non-institutionalized elderly persons in a regional hub city in the north of Minas Gerais.

\section{METHODS}

A cross-sectional and analytical study of noninstitutionalized elderly living in the city of Montes Claros, northern Minas Gerais, was conducted. The city has a population of approximately 400,000 inhabitants and is the main regional urban hub.

Sampling was probabilistic by cluster and performed in two stages. In the first stage, the census tract was used as the sampling unit, with 42 of the 362 urban census tracts in the city randomly selected. In the second stage, the number of households was defined, according to the population density of individuals aged 60 or over. At this stage, more households were allocated in the sectors with the highest number of elderly persons, in order to produce a more representative sample.

The sample calculation considered a total population of 30,790 elderly persons (according to IBGE data), a margin of error of $5 \%$, a confidence level of $95 \%$ and a prevalence of $28.5 \%$, as this is the median observed in a systematic review study. ${ }^{10}$ As cluster sampling was employed, the identified number was multiplied by a correction factor (deff) of two and $10 \%$ was added for possible losses. Thus, the minimum number of persons in the sample size calculation of the study was 682 . 
Elderly persons who were considered by their caregivers/family members to be unable to answer the questions or those who refused to participate in the study were excluded. Elderly persons who were unable to participate in at least three visits on different days and times, even with prior appointments, were considered losses.

Data collection was carried out in the homes of the elderly persons between May and July 2013. Interviewers, who were graduates in nursing, were trained and a pilot study was developed before the collection of data for analysis. The census tracts were visited clockwise from a predetermined point. The data collection instrument was based on similar population-based studies. The pilot study data, from a specially drawn census tract, was not included in the final analysis.

The independent variables studied were: gender (male vs. female), age (younger than 80 years $\mathrm{x} 80$ years or older), self-reported skin color, marital status (married or civil union $\mathrm{x}$ without partner), family income (greater than one minimum salary $\mathrm{x}$ equal to or lower than one minimum salary), self-perceived health (positive $\mathrm{x}$ negative), frailty (defined by the Edmonton Frail Scale, which evaluates nine domains with a score from zero to 17 and defines frailty as a score greater than six), ${ }^{21}$ fear of falling (no x yes), presence of chronic comorbidities (hypertension, diabetes mellitus, osteoporosis, arthritis/arthrosis/rheumatism, heart disease, all self-reported - no x yes), polypharmacy (defined as the continuous use of five or more drugs - no x yes), hospitalization in the last year (no $\mathrm{x}$ yes), depressive symptoms (defined by the reduced version of the Yesevage Geriatric Depression Scale - GDS 15, wherein a score equal to or greater than six identifies depressive symptoms), ${ }^{22}$ functional mobility through the Timed Up and Go test (where a time equal to or greater than 20 seconds is suggestive of more difficult mobility for the elderly) ${ }^{23}$ and smoking (no x yes). All the variables were dichotomized for data analysis.

The prevalence of falls in the previous 12 months was taken as the outcome variable. Initially, bivariate associations were established between the record of falls and the variables using the chisquared test. In a second step, variables that were associated to a level of $20 \%(p<0.20)$ were jointly evaluated by logistic regression. At this stage, the odds ratio was calculated (OR) with respective confidence intervals of $95 \%$, to evaluate the magnitude of associations, assuming a significance level of $5 \%(p<0.05)$. Analysis was performed using the Statistical Package for the Social Sciences (SPSS), version 17.0 (SPSS for Windows, Chicago, USA) program.

All the participants were fully informed about the research and gave their consent by signing a Free and Informed Consent Form or by a digital fingerprint record, when unable to sign. The research project was approved by the Research Ethics Committee of the Universidade Estadual de Montes Claros (Montes Claros State University) (Process no 173397).

\section{RESULTS}

The study included 683 predominantly female elderly persons, aged between 60 and 98 years, with a mean of 70.9 years $(S D \pm 8.08)$. Most described their skin color as brown (57.1\%). There was a predominance of married elderly persons (48.6\%). Among the respondents, most reported having up to four years of study, and $26.1 \%$ had no schooling. These and other features of the group are presented in Table 1. 
Table 1. Sociodemographic characteristics of elderly persons in Montes Claros, Minas Gerais, 2013.

\begin{tabular}{|c|c|c|}
\hline Variables & $\mathrm{n}$ & $\%$ \\
\hline \multicolumn{3}{|l|}{ Gender } \\
\hline Female & 443 & 64.9 \\
\hline Male & 240 & 35.1 \\
\hline \multicolumn{3}{|l|}{ Age } \\
\hline 60 to 69 years & 340 & 49.8 \\
\hline 70 to 79 years & 237 & 34.7 \\
\hline More than 80 years & 106 & 15.5 \\
\hline \multicolumn{3}{|l|}{ Skin color/Ethnic Background } \\
\hline Brown/Mixed Race & 390 & 57.1 \\
\hline Black/Afro-Brazilian & 65 & 9.5 \\
\hline White/Caucasian & 214 & 31.3 \\
\hline Yellow/Asian Brazilian & 14 & 2 \\
\hline \multicolumn{3}{|l|}{ Marital Status } \\
\hline Single & 45 & 6.6 \\
\hline Married & 332 & 48.6 \\
\hline Stable Union & 18 & 2.6 \\
\hline Divorced/separated & 54 & 7.9 \\
\hline Widowed & 234 & 34.3 \\
\hline \multicolumn{3}{|l|}{ Family income* } \\
\hline$\leq 1$ minimum wage & 195 & 28.6 \\
\hline 1 to 2 minimum wages & 227 & 33.2 \\
\hline$>2$ minimum wages & 261 & 38.2 \\
\hline \multicolumn{3}{|l|}{ Personal income through retirement } \\
\hline Yes & 431 & 63.1 \\
\hline No & 252 & 36.9 \\
\hline \multicolumn{3}{|l|}{ Religion } \\
\hline Catholic & 474 & 69.4 \\
\hline Evangelical Protestant & 192 & 28.1 \\
\hline Other & 4 & 0.6 \\
\hline None & 13 & 1.9 \\
\hline \multicolumn{3}{|l|}{ Practice religion } \\
\hline Yes & 559 & 81.8 \\
\hline No & 124 & 18.2 \\
\hline
\end{tabular}




\begin{tabular}{|c|c|c|}
\hline Variables & $\mathrm{n}$ & $\%$ \\
\hline \multicolumn{3}{|l|}{ Educational level } \\
\hline Never studied & 178 & 26.1 \\
\hline 1 to 4 years & 343 & 50.2 \\
\hline$>4$ years & 162 & 23.7 \\
\hline \multicolumn{3}{|l|}{ Living arrangement } \\
\hline Live alone & 82 & 12.0 \\
\hline Live only with partner & 119 & 17.4 \\
\hline Live with other family members & 479 & 70.1 \\
\hline Live with non-family members & 3 & 0.4 \\
\hline
\end{tabular}

* Minimum wage at time of study (2013) $=\mathrm{R} \$ 678.00$

In relation to health and healthcare, described in Table 2, the majority of respondents said the public system was the most used type of service $(68.8 \%)$. Health was perceived as good or very good was cited by 291 people (42.6\%). About a quarter of respondents $(23.6 \%)$ reported needing to use five or more drugs of continuously. During the approach, 243 elderly persons $(35.6 \%)$ were classified with some degree of frailty by the Edmonton Scale and 200 (29.3\%) had scores suggestive of depression symptoms according to the Geriatric Depression Scale.

Table 2. Characteristics related to health care and health conditions among elderly persons in Montes Claros, Minas Gerais, 2013.

\begin{tabular}{lcc}
\hline \multicolumn{1}{c}{ Variables } & $\mathbf{n}$ & $\%$ \\
\hline Type of health service most used & & \\
Public (SUS) & 470 & 68.8 \\
Private & 28 & 4.1 \\
Healthcare plan & 120 & 17.6 \\
Couldn't say & 65 & 9.5 \\
Possess healthcare plan & & \\
Yes & 232 & 34.0 \\
No & 451 & 66.0 \\
Use of five or more medications & & \\
Yes & 161 & 23.6 \\
No & 522 & 76.4
\end{tabular}


Continuation of Table 2

\begin{tabular}{|c|c|c|}
\hline Variables & $\mathrm{n}$ & $\%$ \\
\hline \multicolumn{3}{|l|}{ Has caregiver } \\
\hline Yes & 117 & 17.1 \\
\hline No & 566 & 82.9 \\
\hline \multicolumn{3}{|l|}{ Self-perceived health } \\
\hline Very good or good & 291 & 42.6 \\
\hline Reasonable & 302 & 35.4 \\
\hline Poor or very poor & 90 & 13.2 \\
\hline \multicolumn{3}{|l|}{ Smoking } \\
\hline Never smoked & 382 & 55.9 \\
\hline Has smoked & 242 & 35.4 \\
\hline Smoker & 59 & 8.6 \\
\hline \multicolumn{3}{|l|}{ Analysis of Frailty (Edmonton Frail Scale) } \\
\hline Frail & 243 & 35.6 \\
\hline Vulnerable & 152 & 22.2 \\
\hline Not frail & 288 & 42.2 \\
\hline \multicolumn{3}{|l|}{ Depressive symptoms (GDS-15) } \\
\hline Yes & 200 & 29.3 \\
\hline No & 483 & 70.7 \\
\hline \multicolumn{3}{|l|}{ Hospitalization in previous 12 months } \\
\hline Yes & 121 & 17.7 \\
\hline No & 562 & 82.3 \\
\hline \multicolumn{3}{|l|}{ Comorbidity reported* } \\
\hline Yes & 580 & 84.9 \\
\hline No & 103 & 15.1 \\
\hline \multicolumn{3}{|l|}{ Fear of falls } \\
\hline Yes & 490 & 71.7 \\
\hline No & 193 & 28.3 \\
\hline \multicolumn{3}{|l|}{ Timed Up and Go Test } \\
\hline$<20$ seconds & 587 & 85.9 \\
\hline$\geq 20$ seconds & 96 & 14.1 \\
\hline
\end{tabular}

* Self-reported hypertension, diabetes mellitus, osteoporosis, arthritis/arthrosis/rheumatism, heart disease were evaluated. 
For this sample, the prevalence of falls in the previous 12 months prior to the survey was $28.3 \%$, with most individuals suffering a single fall in this period. The main reported cause was slipping/ tripping and most fallers reported needing help to get up (Table 3).
Table 4 presents the results of the bivariate analysis between falls and the main variables. For space limitations, not all the associations investigated are shown.

Table 3. Characteristics linked to falls and postural instability of elderly persons in Montes Claros, Minas Gerais, 2013*.

\begin{tabular}{lcc}
\hline \multicolumn{1}{c}{ Variables } & $\mathrm{n}$ & $\%$ \\
\hline Number of falls in previous 12 months & 85 & 44.0 \\
One & 81 & 42.0 \\
Two to four & 27 & 14.0 \\
$\quad$ Five or more & & \\
Cause of falls & 147 & 76.2 \\
Tripped/slipped & 22 & 11.4 \\
Loss of consciousness & 24 & 12.4 \\
No apparent reason & & \\
Help required in getting up after fall & 101 & 52.3 \\
Yes & 92 & 47.7 \\
No & & \\
Support needed when walking & 167 & 86.5 \\
Walks alone & 26 & 13.5 \\
Use of aids (canes, crutches, wheelchairs) & & \\
Fear of falls & & 81.3 \\
Yes & 157 & 18.7 \\
No & 36 & \\
\hline
\end{tabular}

* Refers only to number of elderly persons who reported falling in last 12 months ( $\mathrm{n}=194)$ 
Table 4. Bivariate analysis for variables associated with falls in previous 12 months among elderly persons in Montes Claros, Minas Gerais, 2013.

\begin{tabular}{|c|c|c|c|c|c|c|}
\hline \multirow[t]{3}{*}{ Independent variables } & \multicolumn{4}{|c|}{ Falls } & \multirow[b]{3}{*}{ OR (CI95\%) } & \multirow[b]{3}{*}{ p-valor } \\
\hline & \multicolumn{2}{|c|}{ Yes } & \multicolumn{2}{|c|}{ No } & & \\
\hline & (n) & $(\%)$ & (n) & $(\%)$ & & \\
\hline Gender & & & & & & $<0.001$ \\
\hline Male & 50 & 25.8 & 190 & 38.9 & 1 & \\
\hline Female & 144 & 74.2 & 299 & 61.1 & $1.83(1.26 ; 2.65)$ & \\
\hline Age & & & & & & 0.020 \\
\hline$<80$ years & 154 & 79.4 & 423 & 86.5 & 1 & \\
\hline$\geq 80$ years & 40 & 20.6 & 66 & 13.5 & $1.66(1.08 ; 2.57)$ & \\
\hline \multicolumn{7}{|l|}{ Marital situation } \\
\hline Married/Stable Union & 84 & 43.3 & 266 & 54.4 & 1 & 0.009 \\
\hline Lived Alone & 110 & 56.7 & 223 & 45.6 & $1.56(1.12 ; 2.18)$ & \\
\hline Income & & & & & & 0.654 \\
\hline$>1$ minimum wage & 141 & 72.7 & 347 & 71.0 & 1 & \\
\hline$\leq 1$ minimum wage & 53 & 27.3 & 142 & 29.0 & $0.92(0.63 ; 1.33)$ & \\
\hline Self-perceived health* & & & & & & $<0.001$ \\
\hline Positive & 60 & 30.9 & 230 & 47.0 & 1 & \\
\hline Negative & 134 & 69.1 & 259 & 53.0 & $1.98(1.39 ; 2.82)$ & \\
\hline Frailty scale & & & & & & $<0.001$ \\
\hline Not frail & 50 & 25.8 & 238 & 51.3 & 1 & \\
\hline Frail/Vulnerable & 144 & 74.2 & 251 & 48.7 & $2.73(1.89 ; 3.94)$ & \\
\hline Fear of falls & & & & & & $<0.001$ \\
\hline No & 36 & 18.6 & 157 & 32.1 & 1 & \\
\hline Yes & 158 & 81.4 & 332 & 67.9 & $2.08(1.38 ; 3.12)$ & \\
\hline Osteoporosis** & & & & & & 0.005 \\
\hline No & 121 & 66.5 & 371 & 77.4 & 1 & \\
\hline Yes & 61 & 33.5 & 108 & 22.6 & $1.73(1.19 ; 2.52)$ & \\
\hline Hypertension** & & & & & & 0.221 \\
\hline No & 49 & 25.3 & 148 & 30.3 & 1 & \\
\hline Yes & 145 & 74.7 & 340 & 69.7 & $1.28(0.88 ; 1.88)$ & \\
\hline Diabetes Mellitus** & & & & & & 0.176 \\
\hline No & 144 & 74.2 & 384 & 79.0 & 1 & \\
\hline Yes & 50 & 25.8 & 102 & 21.0 & $1.31(0.89 ; 1.93)$ & \\
\hline
\end{tabular}




\begin{tabular}{|c|c|c|c|c|c|c|}
\hline \multirow[t]{3}{*}{ Independent variables } & \multicolumn{4}{|c|}{ Falls } & \multirow[b]{3}{*}{ OR (CI95\%) } & \multirow[b]{3}{*}{$\mathrm{p}$-valor } \\
\hline & \multicolumn{2}{|c|}{ Yes } & \multicolumn{2}{|c|}{ No } & & \\
\hline & (n) & $(\%)$ & $(\mathrm{n})$ & $(\%)$ & & \\
\hline Cardiac disease** & & & & & & 0.051 \\
\hline No & 134 & 70.2 & 373 & 77.7 & 1 & \\
\hline Yes & 57 & 29.8 & 107 & 22.3 & $1.48(1.02 ; 2.16)$ & \\
\hline $\begin{array}{l}\text { Arthritis /rheumatism / } \\
\text { arthrosis** }\end{array}$ & & & & & & $<0.001$ \\
\hline No & 99 & 52.7 & 331 & 68.7 & 1 & \\
\hline Yes & 89 & 47.3 & 151 & 31.3 & $1.97(1.39 ; 2.78)$ & \\
\hline Polypharmacy & & & & & & $<0.001$ \\
\hline No & 130 & 67.0 & 392 & 80.2 & 1 & \\
\hline Yes & 64 & 33.0 & 97 & 19.8 & $1.99(1.37 ; 2.89)$ & \\
\hline $\begin{array}{l}\text { Hospitalization in previous } \\
\text { year }\end{array}$ & & & & & & $<0.001$ \\
\hline No & 145 & 74.7 & 428 & 87.5 & 1 & \\
\hline Yes & 49 & 25.3 & 61 & 12.5 & $2.37(1.56 ; 3.61)$ & \\
\hline Depressive symptoms & & & & & & 0.029 \\
\hline No & 125 & 64.4 & 358 & 73.2 & 1 & \\
\hline Yes & 69 & 35.6 & 131 & 26.8 & $1.50(1.06 ; 2.15)$ & \\
\hline Timed Up and Go Test & & & & & & $<0.001$ \\
\hline$<20$ seconds & 152 & 78.4 & 435 & 89.0 & 1 & \\
\hline$\geq 20$ seconds & 42 & 21.6 & 54 & 11.0 & $2.23(1.43 ; 3.47)$ & \\
\hline Smoking & & & & & & 0.040 \\
\hline Never smoked & 121 & 62.4 & 261 & 53.4 & 1 & \\
\hline Smoker/ex-smoker & 73 & 37.6 & 228 & 46.6 & $0.69(0.49 ; 0.97)$ & \\
\hline
\end{tabular}

* The categories regular/poor/very poor were considered as a negative self-perception of health. ${ }^{* *}$ Incomplete information was excluded (patients that did not know about disease)

Table 5 shows the variables in the final model, after multivariate analysis. Female gender, a negative self-perception of health, functional mobility impairment (Timed Up and Go test $\geq 20$ seconds), record of hospitalization in the previous 12 months and frailty according to the Edmonton Frail Scale were associated with the occurrence of falls in the previous 12 months. 
Table 5. Variables associated with the occurrence of falls among elderly persons in Montes Claros, Minas Gerais, 2013.

\begin{tabular}{|c|c|c|}
\hline Independent Variables & OR (CI95\%) & $\mathbf{P}$ \\
\hline Gender & & 0.011 \\
\hline Male & 1 & \\
\hline Female & $1.67(1.13 ; 2.47)$ & \\
\hline Self-perception of health & & 0.040 \\
\hline Positive (Very good/Good) & 1 & \\
\hline Negative (Regular/Poor/Very Poor) & $1.49(1.02 ; 2.20)$ & \\
\hline Frailty scale & & 0.011 \\
\hline Not frail & 1 & \\
\hline Frail/vulnerable & $1.73(1.14 ; 2.64)$ & \\
\hline Timed Up and Go Test & & 0.046 \\
\hline$<20$ seconds & 1 & \\
\hline$\geq 20$ seconds & $1.66(1.02 ; 2.74)$ & \\
\hline Hospitalization in previous year & & 0.008 \\
\hline No & 1 & \\
\hline Yes & $1.82(1.17 ; 2.84)$ & \\
\hline
\end{tabular}

\section{DISCUSSION}

The prevalence of falls in the previous 12 months reported by the elderly persons in the present study was very close to that revealed by a Brazilian study which sampled 100 municipalities in 23 states. ${ }^{11}$ Other Brazilian studies have reported a higher prevalence of falls among the elderly, although these dealt with institutionalized populations. ${ }^{13,14}$ In a review of the topic, the authors observed studies where the prevalence ranged from $15.9 \%$ to $56.3 \%$, although it should be noted that this broad range included samples limited to the institutionalized population and larger studies with a population-based analysis. ${ }^{10}$

Among the sociodemographic variables, only the female gender was associated with falls. This result has been observed by other authors. ${ }^{11-13,16,18}$ There are no specific explanations for this finding, but other authors have highlighted characteristics specific to women such as reduced muscle strength and muscle mass and a higher prevalence of degenerative chronic diseases. ${ }^{11,24} \mathrm{It}$ is worth noting that one study found that the female gender is also associated with recurrent falls. ${ }^{17}$

As for the variable of hospitalization in the year preceding the survey, which was also present in the final model, the risk of falls was greater among elderly persons who had been hospitalized at least once. It was not possible in the present study to verify whether these hospitalizations were directly related to falls or not. However, it can be inferred that this apparent association may be either because a fall is a cause for hospitalization, or as a serious indicator of morbidity and frailty. In this case, immobility, the medications used or the underlying disease, when present, could predispose the individual to falls. Although the association between falls and hospitalizations is common, ${ }^{24,25}$ the association between records of hospitalization in the previous year and the occurrence of falls was observed in one Brazilian 
study, which addressed the occurrence of falls in institutionalized elderly persons. ${ }^{5}$ This finding should be further investigated in future research.

A negative perception of health (classified here as "regular", "poor" or "very poor") was also revealed to be associated with a greater chance of falls. The same association was found in other studies. ${ }^{14-16}$ It is possible that the indicator is closely related to difficulties with balance. ${ }^{14}$ Selfrated health is considered an important health indicator, and is widely used in research and health surveys due to its easy applicability and low cost, compared to other more complex methods. It is a subjective health measure, but reflects the presence of diseases and their impact on the quality of life of individuals. ${ }^{26}$ In Brazil, the development of further research in this area is desirable, according to a recent review on the subject. ${ }^{27}$

The impairment of functional mobility as measured by the Timed Up and Go test was also associated with the occurrence of falls in the present study. This result has also been recorded in other studies. ${ }^{14,28}$ The test is simple to perform and can quickly identify disorders in balance and mobility. It is therefore an essential aspect of geriatric evaluation. ${ }^{23}$ It is imperative, therefore, that this test is routinely implemented in assessments of older people, in order to identify situations of risk and anticipate specific advice and care.

The greater incidence of falls in elder persons with some degree of frailty has been little investigated in Brazilian literature. Only one study conducted in São Paulo recorded a positive association between the variables, with the authors highlighting the possibility of a two-way relationship - in other words, that falls can make elderly persons frail and frailty can cause elderly persons to fall. ${ }^{20}$ Literature from outside Brazil shows this association more frequently, although there is no standardization of studies on how to assess frailty. ${ }^{29,30}$ In the present study, analysis of the studied population by the Edmonton Frail Scale confirmed the association between falls and frailty. This scale is a culturallyadapted instrument validated for the Portuguese language which evaluates nine domains (cognition, health, functional independence, social support, medication, nutrition, mood, urinary continence and functional performance), and is considered a robust instrument due to its multidimensional character. ${ }^{21,31}$

Other variables identified in literature as associated with the occurrence of falls in the elderly were not identified in this study. Some studies investigated morbidities, for example, which revealed an association in bivariate analysis but did not remain in the final model. An association with osteoporosis, arthritis/arthrosis/rheumatism and falls was identified in another study. ${ }^{17}$ It is natural to assume that such conditions lead to uncomfortable situations, with increased sensitivity and stiffness, among other symptoms, contributing to decreased physical ability, affecting mobility and leading to falls. However, these authors did not evaluate functional mobility or frailty, aspects which may include the aforementioned morbidities, in joint multivariate analysis.

The identification of fear of falling as a variable associated with the occurrence of falls in some studies $^{9,32}$ was also not maintained in the final model of the present study. It should be noted, however, that such studies involved a small sample, a fact that may explain the difference observed. Still, we must emphasize that fear of falling is a common profile among the elderly and can make older people feel less confident in performing their daily activities, increasing immobility and postural instability. ${ }^{33}$

The present study did not find a relationship between the presence of depressive symptoms/ depression and the occurrence of falls, unlike other Brazilian $^{13,17}$ and non-Brazilian ${ }^{34,35}$ studies. This is an important relationship and deserves greater attention from researchers and practitioners. There is not always enough information in studies about the prior exclusion of elderly patients using antidepressant medication, an aspect that can affect comparisons between studies.

This study has some significant limitations, such as the fact that the data was obtained from the responses of respondents. Moreover, the consequences of the falls were not included, which could further contribute to defining the impact on health of the elderly in the region, justifying 
more emphatically the need for intervention and more effective prevention measures. Environmental aspects related to falls, such as the characteristics of the site of the fall or the circumstances associated with the event, were not investigated. Also, although there were few losses and refusals relating to participation, the fact that some elderly persons were not at home restricts the more general interpretation of the data. However, it should be emphasized that the study featured a large sample, allowing knowledge to be obtained of a health issue for the elderly that had not been studied in the region.

\section{CONCLUSION}

The study found that falls are a common event among elderly persons living in the community in the north of Minas Gerais. Knowledge of associated variables can contribute to the implementation of more effective preventive measures, as such variables are at least partly subject to intervention. Changes in these factors may decrease the risk of falling and its consequences. To achieve this, comprehensive and multidisciplinary care of the elderly is required.

\section{REFERENCES}

1. Brasil. Ministério da Saúde, Secretaria de Atenção à Saúde, Departamento de Ações Programáticas e Estratégicas, Área Técnica Saúde do Idoso. Atenção à saúde da pessoa idosa e envelhecimento [Internet]. Brasília, DF: MS; 2010 [acesso em 04 fev 2015]. Disponível em: http://bvsms.saude.gov. br/bvs/publicacoes/atencao_saude_pessoa_idosa_ envelhecimento_v12.pdf

2. Veras R. Envelhecimento populacional contemporâneo: demandas, desafios e inovações. Rev Saúde Pública 2009;43(3):548-54.

3. Amorim JSC, Salla S, Trelha CS. Fatores associados à capacidade para o trabalho em idosos: revisão sistemática. Rev Bras Epidemiol 2014;17(4):830-41.

4. Campolina AG, Adami F, Santos JLF, Lebrão ML. Expansion of morbidity: trends in healthy life expectancy of the elderly population. Rev Assoc Med Bras 2014;60(5):434-41.

5. Del Duca GF, Antes DL, Hallal PC. Quedas e fraturas entre residentes de instituições de longa permanência para idosos. Rev Bras Epidemiol 2013;16(1):68-76.

6. Jorge MHPM, Cascão AM, Laurenti R. Em busca de melhores informações sobre a causa básica do óbito por meio de linkage: um recorte sobre as causas externas em idosos - Estado do Rio de Janeiro, Brasil, 2006. Epidemiol Serv Saúde 2012;21(3):407-18.

7. Coutinho ESF, Bloch KV, Coeli CM. One-year mortality among elderly people after hospitalization due to fall-related fractures: comparison with a control group of matched elderly. Cad Saúde Pública 2012;28(4):801-5.
8. Gomes LMX, Barbosa TLA, Caldeira AP. Mortalidade por causas externas em idosos em Minas Gerais, Brasil. Esc Anna Nery Rev Enferm 2010;14(4):779-86.

9. Lopes KT, Costa DF, Santos LF, Castro DP, Bastone AC. Prevalência do medo de cair em uma população de idosos da comunidade e sua correlação com mobilidade, equilíbrio dinâmico, risco e histórico de quedas. Rev Bras Fisioter 2009;13(3):223-9.

10. Sandoval RA, Sá ACAM, Menezes RL, Nakatani AY, Bachion AM. Ocorrência de quedas em idosos não institucionalizados: revisão sistemática da literatura. Rev Bras Geriatr Gerontol 2013;16(4):855-63.

11. Cruz DT, Ribeiro LC, Vieira MT, Teixeira MTB, Bastos RR, Leite ICG. Prevalência de quedas e fatores associados em idosos. Rev Saúde Pública 2012;46(1):138-46.

12. Motta LB, Aguiar AC, Coutinho ESF, Huf G. Prevalência e fatores associados a quedas em idosos em um município do Rio de Janeiro. Rev Bras Geriatr Gerontol 2010;13(1):83-91.

13. Pereira AA, Ceolim MF, Neri AL. Associação entre sintomas de insônia, cochilo diurno e quedas em idosos da comunidade. Cad Saúde Pública 2013;29(3):535-46.

14. Almeida ST, Soldera CLC, Carli GA, Gomes I, Resende TL. Análise de fatores extrínsecos e intrínsecos que predispõem a quedas em idosos. Rev Assoc Med Bras 2012;58(4):427-33.

15. Siqueira FV, Facchini LA, Silveira DS, Piccini RX, Tomasi E, Thumé E, et al. Prevalência de quedas em idosos no Brasil: uma análise nacional. Rev Saúde Pública 2011;27(9):1819-26. 
16. Dantas EL, Brito GEG, Lobato IAF. Prevalência de quedas em idosos adscritos à estratégia de saúde da família do município de João Pessoa, Paraíba. Rev APS 2012;15(1):67-75.

17. Soares WJS, Moraes AS, Ferriolli E, Perracini MR. Fatores associados a quedas e quedas recorrentes em idosos: estudo de base populacional. Rev Bras Geriatr Gerontol 2014;17(1):49-60.

18. Rodrigues IG, Fraga GP, Barros MBA. Quedas em idosos: fatores associados em estudo de base populacional. Rev Bras Epidemiol 2014;17(3):705-18.

19. Hamra A, Ribeiro MB, Miguel OF. Correlação entre fratura por queda em idosos e uso prévio de medicamentos. Acta Ortop Bras 2007; 15(3):143-45.

20. Fhon JRS, Rosset I, Freitas CP, Silva AO, Santos JLF, Rodrigues RAP. Prevalência de quedas em idosos em situação de fragilidade. Rev Saúde Pública 2013;47(2):266-73.

21. Rolfson DB, Majumdar SR, Tsuyuki RT, Tahir A, Rockwood K. Validity and reliability of the Edmonton Frail Scale. Age Ageing 2006;35(5):526-9

22. Almeida OP, Almeida SA. Confiabilidade da versão brasileira da Escala de Depressão em Geriatria (GDS) versão reduzida. Arq Neuropsiquiatr 1999;57(2-B):421-6.

23. Bischoff HA, Stähelin HB, Monsch AU, Iversen MD, Weyh A, Dechend M, et al. Identifying a cut-off point for normal mobility: a comparison of the timed 'up and go' test in community-dwelling and institutionalised elderly women. Age Ageing 2003;32:315-20.

24. Lebrão ML, Laurenti R. Saúde, bem-estar e envelhecimento: o estudo SABE no Município de São Paulo. Rev Bras Epidemiol 2005;8(2):127-41.

25. Perez M, Lourenco RA. Rede FIBRA-RJ: fragilidade e risco de hospitalização em idosos da cidade do Rio de Janeiro, Brasil. Cad Saúde Pública 2013;29(7):1381-91.

26. Singh-Manoux A, Martikainen P, Ferrie J, Zins M, Marmot M, Goldberg M. What does self rated health measure? Results from the British Whitehall II and French Gazel cohort studies. J Epidemiol Commun H 2006;60:364-72.
27. Pagotto V, Bachion MM, Silveira EA. Autoavaliação da saúde por idosos brasileiros: revisão sistemática da literatura. Rev Panam Salud Publica 2013;33(4):302-10.

28. Aveiro MC, Driusso P, Barham EJ, Pavarini SCI, Oishi J. Mobilidade e risco de quedas de população idosa da comunidade de São Carlos. Ciênc Saúde Coliva 2012;17(9):2481-8.

29. Ensrud KE, Ewing SK, Cawthon PM, Fink HA, Taylor BC, Cauley JA, et al. A comparison of frailty indexes for the prediction of falls, disability, fractures and mortality in older men. J Am Geriatr Soc 2009;57(3):492-8.

30. Gallucci M, Ongaro F, Amici GP, Reginei C. Frailty, disability and survival in the elderly over the age of seventy: evidence from "The Treviso Longeva (TRELONG) Study”. Arch Gerontol Geriatr 2009;48(3):281-3.

31. Fabricio-Wehbe SCC, Cruz IR, Haas VJ, Diniz MA, Dantas RAS, Rodrigues RAP. Reprodutibilidade da versão brasileira adaptada da Edmonton Frail Scale para idosos residentes na comunidade. Rev Latinoam Enferm 2013;21(6):1330-6.

32. Antes DL, Schneider IJC, Benedetti TRB, D’Orsi E. Medo de queda recorrente e fatores associados em idosos de Florianópolis, Santa Catarina, Brasil. Cad Saúde Pública 2013;29(4):758-68.

33. Friedman SM, Munoz B, West SK, Rubin GS, Fried LP. Falls and fear of falling: which comes first? A longitudinal prediction model suggests strategies for primary and secondary prevention. J Am Geriatr Soc 2002;50:1329-35.

34. Choi KW, Lee IS. Fall risk in low-income elderly people in one urban area. J Korean Acad Nurs 2010;40(4):589-98.

35. Tanaka M, Kusaga M, Ushijima K, Watanabe C. Association between depression and fall risk among elderly community residents. Nihon Ronen Igakkai Zasshi 2012;49(6):760-6. 